\title{
Okul Müdürlerinin Iletişim Yeterliklerinin Öğretmenlerin Örgütsel Bağlılığı Üzerindeki Etkisi
}

\author{
Prof. Dr. Çağlar Çağlar \\ Adıyaman Üniversitesi -Türkiye \\ ccaglar@adiyaman.edu.tr
}

\author{
Hasan Çınar (Y.L) \\ Adıyaman il Milli Eğitim Müdürlügüu-Türkiye \\ ht.hasantosun@hotmail.com
}

\begin{abstract}
Özet:
$\mathrm{Bu}$ çalışma ile okul müdürlerinin iletişim yeterliklerinin öğretmenlerin örgütsel bağlılığı üzerindeki etkisi ortaya konulmaya çalışılmıştır. Okul müdürlerinin iletişim yeterliklerini tespit etmek amacıyla araştırmada; Topluer (2008), tarafından Türkçeye uyarlanan "Iletişim Becerileri Ölçeği" ile Dağlı, Elçiçek ve Han (2018), tarafından Türkçeye uyarlanan "Örgütsel Bağlılık Ölçeği" kullanılmıştır. Araştırmaya Adıyaman ilinde görev yapmakta olan 341 öğretmen katılmıştır. Bulgular, iletişim yeterlikleri algısının; okul türüne göre ilkokulda çalışan öğretmenlerin, aynı kurumda çalışma süresine göre süre arttıkça ve mesleki kıdem değişkenine göre 1115 yıl kıdemde olanların algısının daha yüksek olduğu; örgütsel bağlıığın, okul türüne göre ilkokulda çalışan öğretmenlerin, aynı kurumda çalışma süresine göre süre arttıkça ve mesleki kıdem değişkenine göre 11-15 yıl kıdemde olanların algısının daha yüksek olduğu; öğretmenlerin örgütsel bağlılık davranışlarının (varyansın) \%38'inin okul müdürlerinin iletişim yeterlikleri tarafından açıklandığını ortaya koymaktadır.
\end{abstract}

Anahtar Kelimeler: İletişim, Illetişim yeterliği, Örgütsel bağlıık, Okul müdürü

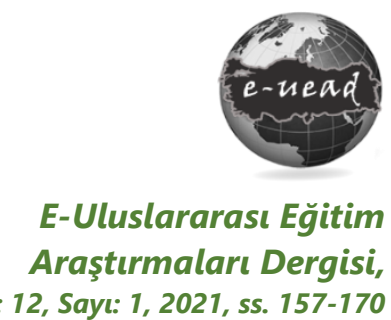

DOI: 10.19160/ijer.831956

Gönderim : 26.11.2020

Kabul: 11.02.2020

\section{Önerilen Atıf}

Çağlar, Ç. ve Çınar, H. (2021). Okul Müdürlerinin İletişim Yeterliklerinin Öğretmenlerin Örgütsel Bağlılığı Üzerindeki Etkisi E-Uluslararası Eğitim Araştırmaları Dergisi, Cilt: 12, Sayı: 1, 2021, ss. 157-170, DOI: 10.19160/ijer.831956 


\section{Giriş}

Iletişim karmaşıktır, ustalık gerektirir, her zaman her yerde karşımıza çıkar ve önemlidir; okul hayatının da her bölümünde yer alır. Üst yöneticiler ve okul müdürleri de zamanlarının büyük bir bölümünü iletişim içinde geçirirler. Yöneticiler, zamanlarının \%70-80'ini kişilerarası iletişim için harcamaktadırlar (Açıkalın, Şişman ve Turan, 2011; Lunenburg ve Ornstein, 2012). Yöneticilerin örgütlerdeki iletişim için ne kadar zaman harcandıkları göz önünde bulundurulduğunda yöneticinin genel iş yükü içinde iletişimin ne kadar merkezi bir yer tuttuğu daha iyi anlaşılabilir. Bu nedenle, eğitim yöneticileri iletişimi yalın bir şekilde anlamak zorundadırlar (Hoy ve Miskel, 2012).

Illetişim, bireyi, grubu, örgütü ve çevresini birbirine bağlayan bir süreçtir. Daha açık belirtmek gerekirse iletişim, örgütün çevreden aldığı girdiler ve örgütün çevreye verdiği çıktılara aracılık eder. İletişim örgütlerde merkezi bir yer işgal eder çünkü örgütlerin yapısı, kapsamı ve faaliyet alanı iletişim teknikleriyle belirlenir. Başka bir ifadeyle iletişim örgütün özüdür (Lunenburg ve Ornstein, 2012). Illetişim, kişilerarası, kurumsal veya yönetimsel süreçleri ve okulların yapısının temelini oluşturmaktadır. Bu yüzden iletişim becerileri, etkili bir yönetici için gerekli bir araçtır (Hoy ve Miskel, 2012). Başka bir ifadeyle okul müdürleri isteklerini açık ve anlaşılır bir şekilde karşısındaki kişilere aktarabilmelidir. Okulun iletişim süreçlerini belirlemede ve üyelerin okuldaki davranışlarını etkilemede, okul yöneticisinin kişisel özellikleri arasında sayılan iletişim becerileri, son derece önemli rol oynar (Gürgen, 1997).

Okul yöneticilerinin amaçları belirlemek, görevleri düzenlemek, çalışanları motive etmek, sonuçları gözden geçirmek ve karar almanın da içinde olduğu çok yönlü görevleri vardır. Okul yöneticileri planlar, organize eder, iş bölümü yapar, yönlendirir, eşgüdümler ve değerlendirir. Yeterli iletişim olmadan görevler başarılı bir şekilde yapılamaz, amaçlara ulaşamaz ve kararlar uygulanamaz (Lunenburg ve Ornstein, 2012; Konan ve Mermer, 2021).

Okul çalışanlarının kendilerinden beklenen görevleri tam olarak kavramaları ve yerine getirmeleri okulda var olan iletişimin etkililiğiyle mümkündür. Bu nedenle etkili bir yönetim sürecinin temelinde etkili bir iletişim sürecinin olduğu söylenebilir (Şimşek, 2003). Okul yönetiminde iletişim önemlidir. Buna bağlı olarak okul müdürlerinin üst düzeyde iletişim yeterliğine sahip olması gerekmektedir. Müdürlerin "iletişim yeterliği" nin düzeyini artırmak üzere gerek hizmet öncesi gerekse hizmet içi eğitim programlarında "iletişim" üzerinde durulması gerektiği açıktır (Toprakçı, 2001).

Kişiler arası ilişkilerde, etkili iletişim becerilerine sahip olma, okul yöneticisinin sahip olması gereken yeterlik alanlarından biridir. Düşüncelerin açık bir biçimde ortaya konulması ve aydınlatılması, çift yönlü iletişime önem verilmesi, iyi bir dinleyici olma, bilginin paylaşımasının sağlanması, karşıdaki kişiye duyarlı olunması ve empatik davranma, dinleyenlerin gereksinimlerinin dikkate alınması, okul müdürlerinin iletişim sürecinde göz önünde bulundurması gereken temel öğelerdir (Şişman, 2012). Okul müdürünün okulda sağlıklı bir iletişim sistemi geliştirirken iletişim sürecinin temel özelliklerini dikkate alması gerekir.

Okul örgütünde, okul müdürü ile öğretmen iletişiminin niteliği, okulun diğer öğeleri olan öğretmen-öğrenci, öğretmen-veli iletişimini etkilemektedir. Bir okulda demokratik bir atmosfer yaratılabilmesi ve amaçların etkili bir biçimde gerçekleştirilebilmesi öncelikle, müdür-öğretmen, öğretmen-müdür iletişimine; yani çift yönlü iletişime ve bu iletişim süreçlerinin niteliğine bağlıdır (Celep, 2000).

Birçok faktörden dolayı okul içi iletişim süreçlerinde engeller meydana gelebilmektedir. Bu durumda iletişimde aksaklıklar ve anlaşılmazlık oluşur. Bu durum insan ilişkilerini olumsuz yönde etkiler. Illetişim sürecinde engeller, bir iletinin verilmesini veya alınmasını güçleştiren tüm faktörlerdir (Ergin ve Birol, 2000). Bu faktörler, okullarda iletişim süreçlerini ve sonuç da okulu olumsuz yönde etkiler.

İletişim sürecini olumsuz etkileyen iletişim engellerine yol açan nedenlerin bir bölümü bilinçli, bir bölümü ise farkında olmadan yapılan davranışların sonucudur (Cüceloğlu, 1994, s.167). Bu nedenle, iletişim sürecinde kaynak tarafından gönderilen iletiler, anlamlarını kaybetmeden, eksiksiz bir biçimde genellikle alıcıya ulaşamazlar. Kaynak tarafından gönderilen ileti ile alıcı 
tarafından anlaşılan iletiler çoğu kez farklılık gösterir. Bu farklılık ne kadar az ise iletişim o kadar sağlıklı; ne kadar fazla ise iletişim o kadar sağlıksız ve hatalıdır. Düşünce yapılarındaki farklılıklar, filtreleme davranışları, örgütsel yapı, aşırı bilgi yüklenmesi, aynı kelimelerin farkıı bireyler için farkı anlamlara gelmesi statü farklılıkları gibi etkenler iletişim sürecinde, kaynaktan alıcıya ulaşıncaya dek iletilerin bozulmasına ya da çarpıtılmasına neden olmaktadır.

Okulun etkililiği açısından iletişim süreci ile ilgili olarak okul müdürlerinin iletişim engelleriyle baş edici bir özellikte gerekir. Okul müdürlerinin bu konulardaki bilgi ve becerisi, okuldaki iklimin oluşumunda ve olumlu iklimin devam ettirilmesinde önemli yer tutar.

Günümüz örgütlerin üzerinde önemle durduğu konulardan biri iş görenlerin örgüte bağlılığıdır. Örgütsel bağlıık olarak adlandırılan bu kavram, işgörenlerin, örgüte sadakatleriyle ilgili tutumu, kendini örgütle özdeşleştirmesine ve örgütte kalıcı olmasına yönelik eğilimi, aktif olarak örgüte katıımı sürdürme derecesi ya da örgüt ile işgörenin amaçlarının bir bütünlük içinde olması olarak farklı biçimlerde ifade edilebilir (Luthans, 1995; Newstrom ve Davis, 1993; Robbins ve Coulter, 2003).

Örgütsel bağlılık, iş görenin örgütü ile olan aidiyet bağı ile üyesi olduğu örgütle iletişimini ve örgüte olan üyeliğini sürdürme arzusunun düzeyini etkilemektedir. Bu düzey, bir ucunda örgütten ayrılma diğer ucunda ise örgüt üyeliğini sürdürme arasında yer alır. Örgütsel bağlıık ne derece güçlüyse, iş görenin örgüt üyeliğini sürdürme arzusu da o kadar yüksek olacaktır. Örgütsel bağlıığın güçlü olmadığı durumlarda iş görenin işten ayrılma ya da yeni arayışlar içine girme olasııı̆ı artmaktadır. Örgütsel bağlıığın düzeyi, işi bırakma ya da işe devam etmenin yanı sıra iş görenin iş başarımı ve motivasyon düzeyini de olumlu ya da oluşuz bir biçimde etkilemektedir. İş görenin örgütle ilgili tutumunu yansıtan örgütsel bağlılığın, işe devamsızlık, geç kalma, işi bırakma, işi yavaşlatma, iş performansı düşüşü sergileme gibi olumsuz iş gören davranışlarını azaltırken örgütsel performansı artırdığı belirtilmektedir (Bülbül, 2007: 1).

Örgütsel bağlılı̆ın yüksek olmasının örgüt için doğuracağı olumlu sonuçlar, işe devamın sağlanması, geç kalmaların veya kaytarmaların azalması ve iş görenlerin örgütün hedeflerini önceleyerek çoğu kez kendi özel amaçlarını ikinci plana atması veya her ikisini özdeşleştirmesidir. Bu durum güdülenmenin yüksek olduğu bir örgüt iklimi anlamına gelmektedir. Örgüt ikliminin açık olduğu durumlar, çalışanları daha mutlu, daha verimli ve daha yüksek bir iş doyumu olması yönünde olumlu etkilemesi, örgütsel amaçların gerçekleşmesine katkı sağlayacaktır (Yücel ve Bektaş, 2012).

Örgütsel bağııığı konu edinen çalışmalar, örgütsel bağlıı̆ın farklı boyutları olduğunu ileri sürmektedirler. Örgütsel bağlılığı, Aronson (1999), ödüle ulaşma ya da cezadan kaçınma için sergilenen tutum ve davranışları tanımlayan uyum, bireyin etkiyi yaratan olguya benzeme isteği duymasını tanımlayan özdeşleşme ve doğru olanı yapma tutumunu tanımlayan içselleştirme aşamalarından oluşan üç boyutlu bir tutum olarak boyutlandıırken, Meyer ve Allen (1991), örgütsel bağlılığı, duygusal, devam ve normatif bağlılı olmak üzere üç boyutu olduğunu ileri sürmektedir.

1. Duygusal Bağlılık: Çalışanların örgüte duygusal bağlııklarını, kendilerini örgüt ile özdeşleştirmeleri ve örgütsel süreçlere katılmaları durumunu ifade etmektedir. Duygusal bağlı̆ı̆ı yüksek olan bireyler "istedikleri için" örgütte kalırlar ve örgütün çıkarları için büyük çaba göstermeye istekli olurlar (Dağlı, Elçiçek ve Han, 2018). Örgütlerde gerçekleşmesi en çok arzu edilen ve çalışanlara aşılanmak istenen bağlılık türü (Afşar, 2011) olan duygusal bağlılık iş görenlerin var olan durumdan kendilerini sorumlu hissetmelerini sağlar ve örgütsel hedeflere ulaşmada daha fazla çaba göstermelerine yol açmaktadır.

2. Devam Bağlıığı: Çalışanların örgütten ayrılmanın maliyetinin yüksek olacağını düşünerek, ihtiyaçları olmaları nedeniyle örgütte kalmaya devam ettikleri durumları tanımlamaktadır. Devam bağlıı̆ında iki temel etken; bireylerin örgüte yapmış oldukları yatırımın düzeyi ile diğer alternatifleri algılamanın azlığıdır. Yatırım düzeyi ne derecede yüksek ve alternatifler ne derecede az ise devam bağlılığı o düzeyde artacaktır.

Devam bağlıı̆̆ının yüksek olduğu çalışanlarda, örgütte çalışmanın sağladığı yarar algısı ve bunların kaybedilme kaygısı yüksektir. Bu durumdan yararlanmaya devam etmek veya kaybetme 
kaygısından kurtulmak için örgütte kalmayı bir zorunluluk olarak görürler. Böyle bir durumda çalışanlar, yalnızca ödüllerin beklentileriyle uyuştuğunda en iyi çabayı gösterirler (Dağlı, Elçiçek ve Han, 2018).

3. Normatif Bağlılı: İşgörenlerin ahlaki olarak örgütte kalmak zorunda oldukları durumları ifade etmektedir. Bu tür bağlılıkta çalışanlar kişisel yararlardan çok ahlaki değerlere önem verirler. Normatif bağlılığı yüksek olan çalışanlar örgütte çalışmaya devam etme duygusunun oluşmasına yol açan toplumsal normlara dayanarak, örgütte çalışmayı kendisi için bir görev olarak görürler. Normatif bağlılıkta bir zorunluluğa vurgu yapılır. Normatif bağlılık, bireylerin kendilerinden beklenen davranışları yapmış olmak ve toplumsal düzen içinde kendisine biçilen rolü yerine getirmek için örgütte kalma davranışı göstermeleri durumunda oluşmaktadır. Bu kişiler var olan kurallara veya otoriteye uymaya oldukça önem verirler.

İşin bazı aşamalarında denetim yetki verme, örgütün vizyonu, mücadele ruhu, ekip çalışması yapma, örgüt kültürü, çabaların karşıı̆̆ını alma, değer verme, örgütün teknolojisi, çalışanı geliştirmeye teşvik etme gibi etmenlerin yanı sıra iletişim de örgütsel bağlıı̆̆ı etkileyen bir etmendir (Balay, 2000).

Araştırmalar, örgütsel iletişimin örgütsel bağlılık üzerinde önemli bir etkisinin olduğunu göstermektedir (Atlamaz, 2019; Erbaş, 2008; Kıraç, 2012; Saltık, Ünsar ve Oğuzhan, 2015; Taşlıyan ve Hırlak, 2014; Tümkaya ve Asar, 2016; Yıldız, 2019). Okul yöneticisinin iletişim becerilerinin de örgüte ilişkin bir özellik olması nedeniyle, öğretmenlerin örgütsel bağlılı̆ı üzerinde önemli bir etkisinin olabileceği düşünülmektedir. Etkili bir okul, okul ve görevleriyle özdeşleşmiş öğretmenlerin varlığı ile mümkündür. Düşük öğretmen bağlıı̆̆ı okul etkililiğini azaltan önemli etkenlerden biridir. Öğretmenlerin okula bağlıı̆ının artmasının okulun etkililiğine katkı sağlayabileceği düşüncesi, bağlılık düzeyini olumlu etkileyebilecek etkenlerin belirlenmesini önemli kılmaktadır. Bu nedenle, araştırmada, okul müdürlerinin iletişim becerilerinin öğretmenlerin örgütsel bağlııkları üzerindeki etkilerinin belirlenmesi amaçlanmıştır.

Araştırmanın problemi "Okul müdürlerinin iletişim yeterliği ile öğretmenlerin örgütsel bağlılığı ne düzeydedir? Bu düzeyler çeşitli değişkenlerden (Cinsiyet, Görev yaptığı okul türü, Aynı okulda çalışma süresi, Mesleki kıdem) etkilenmekte midir? Ve son olarak Okul müdürlerinin iletişim yeterlikleri algısının öğretmenlerin örgütsel bağlılığı üzerinde nasıl bir etki yaratmaktadır?" şeklinde özetlenebilir.

Okul müdürlerinin iletişim yeterlikleriyle öğretmenlerin örgütsel bağlılıları arasında bir ilişkinin olduğu söylenebilir. Bu nedenle öğretmenlerin örgütsel bağlılık düzeylerinin yükseltilmesinde okul müdürlerinin olumlu iletişim kurmaları önemli bir etki oluşturmaktadır. Bu araştırmada okul müdürlerinin iletişim yeterliklerinin öğretmenlerin örgütsel bağlılığı üzerindeki etkisi ortaya konulmaya çalışılmıştır.

\section{YÖNTEM}

\section{Araştırmanın Yöntemi ve Modeli}

Araştırmanın modeli, ilişkisel tarama modeline dayalı betimsel bir çalışmadır. illişkisel tarama modelleri, iki ve daha çok sayıdaki değişken arasında birlikte değişim varlığını ve/ veya derecesini belirlemeye çalışan araştırma modelleridir. İlişki aramalarındaki betimlemeler var olanın belli standartlara uyan ölçülerini bulmaya çalışmaktan çok, birey, nesne vb. durumlar arası ayrımların belirlenebilmesi amacına dönüktür (Karasar, 2008).

\section{Araştırmanın Çalışma Grubu}

Araştırmanın evrenini; 2019/2020 eğitim öğretim yılı, Adıyaman il merkezindeki MEB'e bağlı okul öncesi, ilkokul, ortaokul ve lise okul türlerinde görev yapan 9561 öğretmen oluşturmaktadır. Ölçeklerin yer aldığı formlar, Google anket uygulaması kullanılarak gerçekleştirilmiştir. Formlar, araştırmacı tarafından 710 öğretmene ulaştııılmış. Dağıtılan formlardan 353 adet geri dönüş olmuştur. Elde edilen 353 formun 12 tanesi çeşitli eksikliklerden dolayı değerlendirmeye alınmamıştır. Araştırma analizi için 341 form değerlendirmeye alınmıştır. Örnekleme ilişkin betimsel istatistikler Tablo 1'de verilmiştir. 
Tablo 1. Örnekleme Ilişkin Betimsel Istatistikler

\begin{tabular}{|c|c|c|c|}
\hline Değişkenler & & Frekans(f) & Yüzde (\%) \\
\hline \multirow{2}{*}{ Cinsiyet } & Kadın & 133 & 39 \\
\hline & Erkek & 208 & 61 \\
\hline \multirow{4}{*}{ Çalıştığı Kurum } & Okul Öncesi & 17 & 5 \\
\hline & ilkokul & 84 & 25 \\
\hline & Ortaokul & 174 & 51 \\
\hline & Lise & 66 & 19 \\
\hline \multirow{5}{*}{ Mesleki Kıdem } & $1-5 \mathrm{yll}$ & 25 & 7 \\
\hline & 6-10 yıl & 75 & 22 \\
\hline & $11-15 \mathrm{yll}$ & 85 & 25 \\
\hline & $16-20 \mathrm{yll}$ & 75 & 22 \\
\hline & 21 yıl ve üzeri & 81 & 24 \\
\hline \multirow{4}{*}{ Kurumdaki Çalışma Süresi } & $1-3 \mathrm{yll}$ & 127 & 37 \\
\hline & $4-6 \mathrm{yll}$ & 124 & 36 \\
\hline & $7-9 \mathrm{yıl}$ & 57 & 17 \\
\hline & $10 \mathrm{yıl}$ & 33 & 10 \\
\hline
\end{tabular}

\section{Veri Toplama Araçlart}

Araştırmada kişisel bilgi formunun yanı sıra, Topluer (2008), tarafından Türkçeye uyarlanan "Iletişim Becerileri Ölçeği" ile Meyer, Allen ve Smith (1993) tarafından geliştirilmiş ve Dağlı, Elçiçek ve Han (2018), tarafında Türkçeye uyarlanan "Örgütsel Bağlıık Ölçeği" kullanılıış̧ır.

iletişim Becerileri Ölçeği: Iletişim Yeterlikleri Ölçeği (Communicative Competence Scale), Topluer (2008) tarafından Türkçeye uyarlanmıştır. Ölçeğin açıklayıcı faktör analizinde; anlama ve empati kurabilme, sosyal rahatlık ve destekleme olmak üzere üç boyutu olduğu ortaya konulmuştur. Analizde; faktörlerin toplam varyansa yaptıkları katkının, anlama-empati boyutu için \%39, destekleme boyutu için \%11, ve sosyal rahatlık boyutu için \%10 olduğu görülmektedir. Ortaya çıkan üç boyutun varyansa yaptıkları toplam katkı \%59,97'dir. Doğrulayıcı faktör analizi sonucuna göre; iç tutarlılık katsayıları (Cronbach's Alpha) "anlama ve empati kurabilme" boyutunda .99, "sosyal rahatlık" boyutunda. .76, "destekleme" boyutunda .86, genel olarak da .93 olarak bulunmuştur. Doğrulayıcı faktör analizi verileri ölçeğin güvenilir olduğunu göstermektedir.

Örgütsel Bağlılık Ölçeği: Meyer, Allen ve Smith (1993) tarafından geliştirilmiş ve Dağlı, Elçiçek ve Han (2017) tarafından Türkçeye uyarlanmıştır. "Örgütsel Bağlılık Ölçeği" "duygusal bağlıık, devam bağlılığı ve normatif bağlılık olmak üzere 3 boyut ve 18 madden oluşmaktadır. Açımlayıcı faktör analizine göre ölçeğin birinci faktörü toplam varyansın \%35'ini, ikinci faktörü \%9'unu, üçüncü faktörü \%8 ini açıklamaktadır. Tüm faktörler toplamda örgütsel bağlılığı \%52,72 oranında açıklamaktadır. Ölçeğe ilişkin faktör yükleri .33 ile .80 arasında dağılmaktadır. CronbachAlpha değerlerine bakıldığında; birinci boyutta .80 , ikinci boyutta .73 , üçüncü boyutta .80 ve ölçek toplamında ise .88 olduğu görülmüştür. Bu veriler ölçeğin güvenilir olduğunu göstermektedir.

\section{BULGULAR VE YORUM}

\section{1- Cinsiyet Değişkenine Göre Okul Müdürlerinin Iletişim Yeterliklerine Yönelik Algı ile Öğretmenlerin Örgütsel Bağlılk Düzeyleri}

Okul müdürlerinin iletişim yeterliklerine yönelik algı ile öğretmenlerin örgütsel bağllık düzeylerinin cinsiyet değişkenine göre farklılaşıp farklılaşmadığını belirlemek amacıyla öncelikle Levene homojenlik testi yapılmış (Levene (iletişim Yeterlikleri Algııı) $=.00, p>.05)$; (Levene (Örgütsel bağllık) $=.14$, $\mathrm{p}>.05$ ) varyansların homojen olduğu görüldükten sonra yapılan t-testi sonuçları Tablo 2'de verilmiştir. 
Tablo 2. Iletişim Yeterliklerine Yönelik Algı ile Örgütsel Bağlıı̆̆ın Cinsiyete Göre Farklılaşıp Farklılaşmadığına iliş̧kin t Testi Sonuçları

\begin{tabular}{llllll}
\hline Boyut & Cinsiyet & $\mathbf{N}$ & $\overline{\mathbf{x}}$ & Ss & \multirow{2}{*}{$\mathbf{T}$} \\
\hline $\begin{array}{l}\text { İletişim Yeterliklerine } \\
\text { Yönelik Algı }\end{array}$ & Kadın & 133 & 3,76 &, 56 & \multirow{2}{*}{428} \\
\cline { 2 - 5 } Örgütsel Bağlılık & Erkek & 208 & 3,70 &, 73 & \multirow{2}{*}{, 397} \\
\cline { 2 - 5 } & Kadın & 133 & 3,31 &, 58 \\
\hline
\end{tabular}
$\star \mathrm{p}<.05$

Tablo 2'de görüldüğg̈ gibi, cinsiyet değişkenine göre, Iletişim Yeterliklerine Yönelik Algı [t $(341)=.427 ; \mathrm{p}<.05]$ ve Örgütsel Bağlılık $\quad\left[\mathrm{t}_{(341)}=.397 ; \mathrm{p}<.05\right]$, boyutlarında gruplar arasında istatistiksel olarak anlamlı bir farklılık görülmemektedir. Atlamaz'ın (2019) cinsiyet değişkenine göre iletişim yeterliği ve örgütsel bağlılık algıları açısından gruplar arasında anlamı bir fark olmadığını gösteren bulgusu çalışma bulgularını destekler niteliktedir. İletişim yeterliği boyutunda cinsiyete göre bir farklılaşma olmadığını destekleyen bir çalışma da Çubukçu ve Dündar'a (2003) aittir.

\section{1. Çalıştığı Kurum Değişkenine Göre Okul Müdürlerinin Illetişim Yeterliklerine Yönelik Algı ile Öğretmenlerin Örgütsel Bağlılık Düzeyleri}

Okul müdürlerinin iletişim yeterliklerine yönelik algı ile öğretmenlerin örgütsel bağlılık düzeylerinin çalışılan kurum değişkenine göre farklılaşıp farklılaşmadığını belirlemek amacıyla yapılan Levene homojenlik testi (Levene (iletişim Yeterlikleri Algısı) $=.00, p>.05) ;\left(\right.$ Levene $_{\text {(Örgütsel bağlık) }}=.14$, p>.05) sonucunda varyansların homojen olduğu görülmüş, sonrasında yapılan ANOVA analizi sonuçları Tablo 3'te verilmiştir.

Tablo 3. Iletişim Yeterliklerine Yönelik Algı ile Örgütsel Bağlılığın Öğretmenlerin Çalıştı̆̆ı Kurum Değişkenine Göre Farklılaşıp Farklılaşmadığına İlişkin Analiz Sonuçları

\begin{tabular}{|c|c|c|c|c|c|c|}
\hline Boyut & Kurum & $\mathbf{N}$ & $\overline{\mathbf{x}}$ & ss & $\boldsymbol{F}$ & Fark LSD \\
\hline \multirow{4}{*}{$\begin{array}{l}\text { İletişim } \\
\text { Yeterliklerine } \\
\text { Yönelik Algı }\end{array}$} & Okul Öncesi (1) & 17 & 3.97 & .406 & \multirow{4}{*}{$9.945^{\star *}$} & $1>3$ \\
\hline & ìlkokul (2) & 84 & 3.98 & .388 & & $2>3$ \\
\hline & Ortaokul (3) & 174 & 3.54 & .757 & & $3<1,3<2,3<4$ \\
\hline & Lise (4) & 66 & 3.74 & .628 & & $4>3$ \\
\hline \multirow{4}{*}{$\begin{array}{l}\text { Örgütsel } \\
\text { Bağlılık }\end{array}$} & Okul Öncesi (1) & 17 & 3.39 & .419 & \multirow{4}{*}{$3.126^{* *}$} & \\
\hline & illkokul (2) & 84 & 3.43 & .574 & & $2>3$ \\
\hline & Ortaokul (3) & 174 & 3.19 & .623 & & $3>2$ \\
\hline & Lise (4) & 66 & 3.29 & .654 & & \\
\hline
\end{tabular}

Tablo 3. incelendiğinde iletişim yeterliklerine yönelik algı ile öğretmenlerin çalışmakta olduğu kurum değişkeni arasında gruplar arasında anlamlı bir farklılık bulunduğu görülmektedir $(f=9.945 ; p<.05)$. Farkın kaynağını görebilmek amacıyla yapılan LSD testi sonuçlarına göre ilkokulda çalışan öğretmenlerin iletişim yeterliklerine yönelik algı düzeylerinin $(\bar{x}=3.98)$, ortaokullarda çalışan öğretmenlerin iletişim yeterliklerine yönelik algı düzeylerine $(\bar{x}=3.54)$ göre daha olumludur. İlkokullarda çalışan öğretmenlerin iletişim yeterliklerine yönelik algı düzeyleri $(\bar{x}=3.98)$ ile liselerde çalışan öğretmenlerin iletişim yeterliklerine yönelik algı düzeyleri $(\bar{x}=3.79)$, ortaokullarda çalışan öğretmenlerin iletişim yeterliklerine yönelik algı düzeylerine $(\bar{x}=3.54)$ göre daha olumludur. İletişim yeterliği boyutunda benzer bir sonuç Çubukçu ve Dündar (2003) ve Gülmez'in (2017) çalışma bulgularında da ortaya çıkmaktadır.

\subsection{Mesleki Kıdem Değişkenine Göre Okul Müdürlerinin İletişim Yeterliklerine Yönelik Algı ile Öğretmenlerin Örgütsel Bağlılık Düzeyleri}

Okul müdürlerinin iletişim yeterliklerine yönelik algı düzeyi ile öğretmenlerin örgütsel bağlıık düzeylerinin mesleki kıdem değişkenine göre farklılaşıp farklılaşmadığını belirlemek

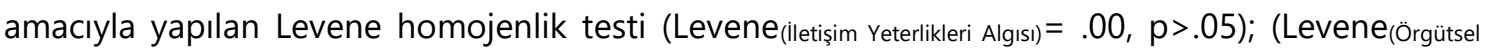
bağlık $=.14, p>.05$ ) sonucunda varyansların homojen olduğu görüldükten sonra yapılan ANOVA analizi sonuçları Tablo 4 'te verilmiştir. 
Tablo 4. Iletişim Yeterliklerine Yönelik Algı ile Örgütsel Bağlılı̆ın Öğretmenlerin Mesleki Kıdem Değişkenine Göre Farklılaşıp Farklılaşmadığına İlişkin Analiz Sonuçları

\begin{tabular}{|c|c|c|c|c|c|c|}
\hline Boyut & Kıdem & $\mathbf{n}$ & $\overline{\mathbf{x}}$ & Ss & $\mathbf{F}$ & Fark LSD \\
\hline \multirow{5}{*}{$\begin{array}{l}\text { İletişim } \\
\text { Yeterliklerine } \\
\text { Yönelik Algı }\end{array}$} & $1-5$ yıl (1) & 25 & 3.62 & .84 & \multirow{5}{*}{3.666} & \\
\hline & 6-10 yıl (2) & 75 & 3.63 & .66 & & \\
\hline & $11-15$ yıl (3) & 85 & 3.83 & .54 & & \\
\hline & $16-20$ yıl (4) & 75 & 3.65 & .77 & & \\
\hline & 21 yıl ve üzeri (5) & 81 & 3.88 & .60 & & \\
\hline \multirow{5}{*}{$\begin{array}{l}\text { Örgütsel } \\
\text { Bağlılık }\end{array}$} & $1-5$ yıl (1) & 25 & 3.27 & .77 & \multirow{5}{*}{4.374 * } & \\
\hline & 6-10 yıl (2) & 75 & 3.07 & .63 & & $2<3,2<5$ \\
\hline & $11-15$ yıl (3) & 85 & 3.37 & .56 & & $3>2$ \\
\hline & $16-20$ yıl (4) & 75 & 3.21 & .65 & & \\
\hline & 21 yıl ve üzeri (5) & 81 & 3.43 & .52 & & $5>2$ \\
\hline
\end{tabular}

Tablo 4 incelendiğinde öğretmenlerin iletişim yeterliklerine yönelik algı ile öğretmenlerin mesleki kıdem değişkeni arasında anlamlı bir farklıık gözlenmezken öğretmenlerin örgütsel bağlıı̆ı ile öğretmenlerin mesleki kıdem değişkeni arasında anlamlı bir fark olduğu görülmektedir. Analiz sonucuna göre; mesleki kıdemi 21 yıl ve üzeri olan öğretmenlerin örgütsel bağlılık düzeyinin $(\bar{x}=3.43)$, mesleki kıdemi $16-20$ yıl olan öğretmenlerin örgütsel bağlıık düzeylerine $(\bar{x}=3.21)$ ve mesleki kıdemi $6-10$ yıl olan öğretmenlerin örgütsel bağlılık düzeylerine $(\bar{x}=3.07)$ göre daha yüksek olduğu görülmektedir. Mesleki kıdemi 11-15 yıl olan öğretmenlerin örgütsel bağlılık düzeyleri ( $\bar{x}=3.37$ ) diğerlerine oranla en düşük düzeydedir. Atlamaz (2019), çalışmasında mesleki kıdem değişkenine göre iletişim yeterliği boyutunda kıdem arttıkça algının yükseldiğini, örgütsel bağlılık boyutunda ise anlamlı bir fark olmadığı bulgusuna ulaşmıştır. Gülmez'e (2019) göre mesleki kıdem değişkenine göre iletişim yeterliği boyutunda kıdem arttıkça algı yükselmekte iken Çubukçu ve Dündar'a (2003) göre anlamlı bir fark görülmemektedir.

\subsection{Bulunulan Kurumdaki Çalışma Süresi Değişkenine Göre Okul Müdürlerinin İletişim Yeterliklerine Yönelik Algı ile Öğretmenlerin Örgütsel Bağlılık Düzeyleri}

Öğretmenlerin okul müdürlerinin iletişim yeterliklerine yönelik algı düzeyleri ile örgütsel bağlıık düzeylerinin bulunulan kurumdaki çalışma süresi değişkenine göre farklılaşıp farkılıaşmadığını belirlemek amacıyla yapılan Levene homojenlik testi (Levene (lietişim Yeterlikleri Algııı) $=$ $.00, p>.05)$; (Levene (Örgütsel bağlık) $=.14, p>.05$ ) sonucunda varyansların homojen olduğu görüldükten sonra yapılan ANOVA analizi sonuçları Tablo 5'te verilmiştir.

Tablo 5. Iletişim Yeterliklerine Yönelik Algı ile Örgütsel Bağlı̆ğın Öğretmenlerin Bulundukları Kurumdaki Çalışma Süresi Değişkenine Göre Farklılaşıp Farklılaşmadığına iliş̧kin Analiz Sonuçları

\begin{tabular}{|c|c|c|c|c|c|c|}
\hline Boyut & Çalışma Süresi & $\mathbf{N}$ & $\overline{\mathbf{x}}$ & Ss & $\mathbf{F}$ & Fark LSD \\
\hline \multirow{4}{*}{$\begin{array}{l}\text { İletişim } \\
\text { Yeterliklerine } \\
\text { Yönelik Algı }\end{array}$} & $1-3$ yıl (1) & 127 & 3.58 & .75 & \multirow{4}{*}{$7.159^{\star *}$} & $1<3,1<4$ \\
\hline & 4-6 yıl (2) & 124 & 3.67 & .71 & & $2<3,2<4$ \\
\hline & $7-9$ yıl (3) & 57 & 3.92 & .36 & & $3>1,3>2$ \\
\hline & 10 yıl ve üzeri (4) & 33 & 4.08 & .33 & & $4>1,4>2$ \\
\hline \multirow{4}{*}{ Örgütsel Bağlılık } & $1-3$ yıl (1) & 127 & 3.17 & .64 & \multirow{4}{*}{$3.785^{\star *}$} & $1<3,1<4$ \\
\hline & $4-6$ yıl (2) & 124 & 3.26 & .66 & & \\
\hline & $7-9$ yıl (3) & 57 & 3.43 & .42 & & $3>1$ \\
\hline & 10 yıl ve üzeri (4) & 33 & 3.48 & .58 & & $4>1$ \\
\hline
\end{tabular}

${ }^{* *} \mathrm{p}<.01$

Tablo 5. incelendiğinde iletişim yeterliklerine yönelik algı düzeyi ile öğretmenlerin bulundukları kurumdaki çalışma süreleri değişkenlerine göre gruplar arasında anlamlı bir fark olduğu görülmektedir ( $f=7.159 ; p<.01)$.

Öğretmenlerin bulundukları kurumdaki çalışma süreleri arttıkça iletişim yeterliklerine yönelik algı düzeylerinin yükseldiği görülmektedir. Bulundukları kurumdaki çalışma süreleri 1-3 yıl olan öğretmenlerin iletişim yeterliklerine yönelik algı düzeyleri $(\bar{x}=3.58)$ en düşük, çalışma süreleri 10 yıl ve üzeri olan öğretmenlerin iletişim yeterliklerine yönelik algı düzeyleri $(\bar{x}=4.08)$ en yüksek 
olduğu görülmüştür. Oysa Çubukçu ve Dündar (2003), bulunulan okuldaki hizmet süresi değişkenine göre bir fark olmadığını ileri sürmektedirler.

Öğretmenlerin örgütsel bağlılık düzeyleri ile öğretmenlerin bulundukları kurumdaki çalışma süreleri değişkenlerine göre gruplar arasında anlamlı bir fark olduğu görülmektedir $(f=3.785$; $\mathrm{p}<.01)$. Öğretmenlerin bulundukları kurumdaki çalışma süreleri arttıkça örgütsel bağlıık düzeylerinin yükseldiği görülmektedir.

\section{2- Okul Müdürlerinin Iletişim Yeterliklerine Yönelik Algı Düzeyinin Öğretmenlerin Örgütsel Bağlılık Düzeyleri Üzerindeki Etkisi}

Tablo 6. İletişim Yeterliklerinin, Öğretmenlerin Örgütsel Bağllıklarının Yordamasına Ilişkin Regresyon Analizi

\begin{tabular}{cccccccc}
\hline $\begin{array}{c}\text { Bağımsız } \\
\text { Değişken }\end{array}$ & $\begin{array}{c}\text { Bağımlı } \\
\text { Değişken }\end{array}$ & B & $\begin{array}{c}\text { Standart } \\
\text { Hata }\end{array}$ & Beta & F & $R$ & $\Delta R^{2}$ \\
\hline $\begin{array}{c}\text { Iletişim } \\
\text { Yeterliklerine } \\
\text { Yönelik Algı }\end{array}$ & $\begin{array}{c}\text { Örgütsel } \\
\text { Bağlılık }\end{array}$ & 1.183 & .15 & .613 & $204.37^{* *}$ & .61 & $.38^{* *}$ \\
$* * \mathrm{p}<.01$ & & & & &
\end{tabular}

Okul müdürlerinin iletişim yeterliklerine yönelik algı düzeyinin öğretmenlerin örgütsel bağlılık düzeyleri üzerindeki etkisini belirleyebilmek amacıyla yapılan regresyon analizinin sonuçları Tablo 6'da verilmiştir.

İlişkinin yordanmasına yönelik yapılan regresyon analizi sonuçlarına göre; Okul müdürlerinin iletişim becerilerinin öğretmenlerin örgütsel bağııı̆ı davranışlarını olumlu yönde ve orta düzeyde etkilediği görülmektedir. Modelin açıklama gücü olarak ifade edilen $R^{2}$ değeri .38 olarak hesaplanmıştır $\left(R^{2}=.38 ; p<.01\right)$. Bu değer öğretmenlerin örgütsel bağlılık puanlarının (varyansın) \%38'inin okul müdürlerinin iletişim yeterlikleri puanı tarafından açıklandığını göstermektedir. Okullar müdür, müdür yardımcıları, öğretmenler ve öğrencileriyle beraber bir yaşam alanı oluşturmaktadır. Bu yaşam alanındaki ilişkilerin olumlu ya da olumsuz olmasında şüphesiz tüm paydaşların katkısı vardır. Ancak okul müdürleri okulun diğer tüm üyelerinin amiri konumunda olduklarından ve okulun yönetiminde son söz sahibi olduklarından örgüt iklimine diğer üyelerden daha fazla etki ederler. Öyle ki yönetim tarzı, kişisel özellikleri, işindeki profesyonelliği ve olumlu iletişim becerileri sayesinde okullarında, aile olma ve birlikte çalışma arzusunu arttıran okul müdürleri vardır. Diğer yandan tüm öğretmenlerin şikayetçi olduğu ve olumsuz tutumlarından dolayı öğretmenlerin büyük bölümünün diğer okullara tayin istediği okul müdürleri de vardır. Dolayısıyla okul müdürlerinin iletişim becerileri öğretmenlerin örgütsel bağlıı̆ına etki eden en önemli faktörlerden biridir

\section{TARTIŞMA, SONUÇ VE ÖNERILER}

Okul müdürlerinin iletişim becerilerinin öğretmenlerin örgütsel bağlılıkları üzerindeki etkisinin ele alındığı çalışmada şu sonuçlara ulaşımıştır;

Illetişim yeterliklerine yönelik algı ile öğretmenlerin çalışmakta olduğu kurum değişkeni arasında anlamlı bir farklılık bulunduğu ortaya çıkmıştır. illkokulda çalışan öğretmenlerin okul müdürlerinin iletişim yeterliklerine yönelik algı düzeyleri, ortaokulda çalışan öğretmenlerden daha olumlu çıkmıştır. Daha önce yapılan araştırmalarda da okul müdürleri iletişim becerisi bakımından öğretmenler tarafından olumlu, yeterli vb. olarak değerlendirilmekle birlikte bu değerlendirmenin farklı okul kademelerine göre değişiklik gösterdiğine dikkat çekilmiştir. Çınar'ın (2010) yaptığı araştırmada branş öğretmenleri sınıf öğretmenlerine nazaran okul müdürlerini iletişim sürecinde daha ilgili bulmuşlardır. Ortaokullarda çalışan öğretmenlerin iletişim yeterliklerine yönelik algı düzeylerinin diğerlerine oranla düşük çıkmasında okul öncesi ve ilkokul öğretmenlerinin sınıf içi ve dışındaki iş ve işlemlerinde okul müdürlerinden daha bağımsız davranabilmelerinin etkisi 
olabilir. Okul öncesi ve ilkokul öğretmenleri ders programı, sınıf içi düzenlemeler, diğer öğretmenlerle birlikte eğitim etkinlikleri düzenleme vb. konularda ortaokul ve liselerde çalışan branş öğretmenlerinden daha fazla özgürlük alanına sahiptir. Bu durum okul öncesi ve ilkokul öğretmenlerinin okul müdürleriyle olası anlaşmazlık alanlarını azalttığından okul öncesi ve ilkokul öğretmenlerinin okul müdürlerinin iletişim yeterliklerine bakış açıları daha olumludur.

Ortaokullarda çalışan öğretmenlerin iletişim yeterliklerine yönelik algı düzeyinin, liselerde çalışan öğretmenlerin iletişim yeterliklerine yönelik algı düzeyinden daha düşük olmasında ise bu iki okul düzeyindeki öğrencilerin farklı yaş aralığında ve bu yaşların gerektirdiği farklı gelişim özelliklerinden kaynaklandığı söylenebilir. Ortaokul 11-14 yaş aralığında ergenlik dönemine denk gelmektedir. Doğan (2007) ergenlik dönemini ruh bilimciler, çalkantılı, tedirgin çelişkilerle dolu, hızlı bir büyüme çağı, bağımsızlığa yönelme ve cinsel uyanış dönemi olarak tanımlanmaktadır. Normal her ergen az ya da çok bu ruhsal sıkıntıları geçirebilir. Ergenin hem kendi içinde hem çevre ile ilişkilerinden kaynaklanan beklentileri vardır. Ergenin yeni bedeni, yeni hormonlara, ana baba yerine geçen yeni ilişkilere, yeni değer yargılarına uyumu kolay olmamaktadır. Bu nedenle her ergende zaman zaman çok çeşitli tepkiler, sorunlar ortaya çıkabilmektedir (Mangır ve ÇağatayAral, 1992). Tüm bu gelişim özellikleri ortaokulların daha gürültülü ve öğrenci kavgaları gibi istenmeyen davranışların daha sık yaşanmasına ve dolayısıyla hem öğretmenlerde hem de okul müdürlerinde stres düzeyinin daha fazla olmasına neden olmaktadır. Lise öğrencileri ise ergenlikteki çalkantılı dönemi aşmış ve daha durgun gelişim özellikleri göstermektedir.

Örgütsel bağlılık ile öğretmenlerin çalışmakta olduğu kurum değişkeni arasında ilişki de bu verilerle paralellik göstermektedir. Okul öncesi eğitim kurumlarında çalışan öğretmenlerin örgütsel bağlılığı, ilkokullarda çalışan öğretmenlerin örgütsel bağlılığı ve liselerde çalışan öğretmenlerin örgütsel bağlılıklarının; ortaokullarda çalışan öğretmenlerin örgütsel bağlıık düzeylerine göre daha yüksek olduğu görülmüştür. Balay (2014) çalışmasında, liselerde görev yapan öğretmenlerin diğer düzeylerde eğitim yapan okullarda görev yapanlara göre bağlılık düzeylerinin daha yüksek çıkmasında sağlanan imkânların belirleyici olabileceğini belirtmiştir. Serin ve Buluç (2012) araştırmasında örgütsel bağlılık anketine verilen cevaplar analiz edildiğinde, öğretmenlerin ankette yer alan maddelere verdikleri cevapların ortalamalarının bulgularımızla paralel olarak "katılıyorum" derecesinde olduğu ortaya çıkmıştır. Bu neticeye göre öğretmenlerin genel olarak okullarına bağlı oldukları söylenebilir ancak yine sonuçlara göre çok yüksek bir bağlılıktan da söz etmek mümkün değildir.

Öğretmenlerin okul müdürlerinin iletişim becerilerine yönelik algı düzeyleri ile öğretmenlerin mesleki kıdem değişkeni arasında anlamlı bir ilişkinin olmadığı görülmüştür. Can (2001), yaptığı çalışmada hizmet süresi değişkenine göre, okul müdürlerinin iletişim becerilerine ilişkin öğretmenlerin görüşleri arasında; tutumlar, dinleme becerisi, dönüte verilen önem ve iletişimin zamanlaması boyutlarında farklııık bulunmuştur. Hizmet süresi fazla olan öğretmenler belirtilen boyutlarda okul müdürlerinin iletişim becerilerini daha etkili bulmaktadırlar.

Öğretmenlerin örgütsel bağlıık düzeyleri ile öğretmenlerin mesleki kıdem değişkeni arasında anlamlı bir ilişkinin bulunduğu görülmektedir. Analiz sonucu esas alınarak mesleki kıdem arttıkça örgütsel bağlııı düzeyinin arttığı söylenebilir. Çetin (2011) yaptığı araştırmada benzer bir sonuca ulaşmıştır.

Öğretmenlerin bulundukları kurumdaki çalışma süreleri arttıkça iletişim yeterliklerine yönelik algı düzeylerinin yükseldiği görülmektedir. Okul müdürlerinin her birinin yaptığı iş biri birine benzemesine rağmen kişilik özellikleri, yaşanmışlıkları, aldıkları eğitim, mesleki kıdemleri gibi özellikler onları farklılaştırmaktadır. Öğretmenlerin aynı kurumdaki çalışma süreleri uzadıkça okul müdürünün kişilik özelliklerini, yönetim tarzını vb. özelliklerini daha fazla bildikleri kabul edilebilir bir olgudur. Öğretmen ve okul müdürünün aynı okulda çalışma süresi uzadıkça karşıııkı olarak tanınma düzeyi artacaktır. Biri birlerini yakından tanıma imkanına sahip olan bireylerin kuracakları iletişim daha iyi olacağından aynı kurumda çalışma süresi uzadıkça öğretmenlerin okul müdürlerinin iletişim yeterliklerine yönelik algıları daha yüksek çıkmaktadır.

Öğretmenlerim örgütsel bağlıığı ile öğretmenlerin bulundukları kurumdaki çalışma süreleri arasındaki ilişkide de benzer bir durum vardır. Öğretmenlerin bulundukları kurumdaki çalışma 
süreleri arttıkça örgütsel bağlılık düzeylerinin yükseldiği görülmektedir. İnsanlar sosyal bir varlık olarak vakit geçirdiği insanlarla ve çevrelerle duygusal bağ kurmaktadır. Bir okula yeni atanan öğretmenin yeni ortama uyum sağlaması belli bir zaman alacaktır. Zamanla okulun iklimine ve kültürüne uyum sağlayan öğretmenler örgütsel sosyalleşme sayesinde zamanla kendilerini okulun bir parçası, örgütün bir üyesi olarak hissederler. Öğretmenlerin aynı kurumdaki çalışma süreleri uzadıkça fiziki ve sosyal çevreye alışma ve uyumu da daha fazla olmaktadır. Bu sebeplerden ötürü aynı kurumdaki çalışma süresi uzadıkça öğretmenlerin örgütsel bağlıık düzeyleri artmaktadır. Çetin (2011) yaptığı araştırmada çalışanların kurumlarındaki çalışma süresi ile doğru orantılı olarak örgütsel vatandaşlık davranışında artış olduğu belirtmektedir. Ordu, Bakay ve Tanrıöğen (2010) yaptıkları çalışmada benzer sonuçlara ulaşmışlardır.

\section{Öneriler}

1-. Bu araştırmadan elde edilen bulgular öğretmenlerin örgütsel bağlılık davranışlarının (varyansın) \%38'inin okul müdürlerinin iletişim yeterlikleri tarafından açıklandığını ortaya koymaktadır. Bu, oldukça yüksek bir orandır. Öğretmenlerin örgütsel bağlılıklarının artırılması amacıyla okul müdürlerinin iletişim yeterliklerinin artııılması için Milli Eğitim Bakanlığınca hizmet içi eğitim kursları yerinde bir uygulama olacaktır. Göreve yeni başlayan okul müdürleri gerekli görülen diğer alanlarla birlikte mutlaka örgüt içi iletişimini sağlayacak bilgi ve beceriye sahip olmalıdır.

2- Araştırma bulgularından elde edilen veriler aynı kurumda çalışma süresi uzadıkça öğretmenlerin örgütsel bağlılığının arttığını göstermektedir. Öğretmenlerin görev yaptıkları eğitim kurumunda daha uzun süre çalışmalarını teşvik edecek uygulamalar yapılmalıdır. Milli Eğitim Bakanlığı öğretmenlerin bazı bölgelerde ve okullarda daha uzun süre çalışmalarını sağlamak amacıyla yıllık kazanılan hizmet puanını \%50 artırımlı uygulamaktadır. Bu uygulamanın benzeri öğretmenlerin aynı okuldaki çalışma süresini uzatmak amacıyla da uygulanabilir.

\section{KAYNAKLAR}

Açıkalın, A., Şişman, M. ve Turan, S. (2011). Bir insan olarak okul müdürü. Ankara: Pegem Akademi.

Afşar, S. T. (2011). Çalışma yaşam kalitesinin örgütsel bağlılı düzeyi üzerindeki etkisi: Devlet ve vakıf üniversitelerinde çalışan akademisyenler üzerine nicel bir araştırma. Yayınlanmamış Doktora Tezi, Hacettepe Üniversitesi Sosyal Bilimler Enstitüsü, Ankara.

Aronson, E. (1999). The social animal. New York: Worth Publishers.

Atlamaz, S. (2019). Ortaöğretim kurumlarında çalışan öğretmenlerin yöneticilerinin iletişim yeterliği algıları ile örgütsel bağlılıları arasındaki ilişkinin incelenmesi. Yayınlanmamış Yüksek Lisans Tezi. Marmara Ün. Eğitim Bilimleri Enstitüsü. İstanbul

Balay, R. (2000). Örgütsel bağlılı. Ankara: Nobel Yayınevi.

Balay, R. (2014). Yönetici ve öğretmenlerde örgütsel bağlılı. Ankara: Pegem Akademi Yayıncılık.

Bülbül, M. (2007). Örgütsel bağlıık ve kamu kuruluşlarına yönelik araştırma. Yayınlanmamış Yüksek Lisans Tezi. Kahramanmaraş Sütçü İmam Üniversitesi, Sosyal Bilimler Enstitüsü, Kahramanmaraş.

Can, N. (2001). Yönetici adaylarının okul müdürlerinin iletişim becerilerine ilişkin görüşleri, Eğitim Araştırmaları. 5(1): 36-44.

Cüceloğlu, D. (1994). Yeniden insan insana. İstanbul: Remzi Kitabevi.

Çetin, F. (2011). Örgütsel vatandaşlık davranışlarının açıklanmasında örgütsel bağlıık, iş tatmini, kişilik ve örgüt kültürünün rolü. Yayınlanmamış Doktora Tezi, Ankara Üniversitesi Sosyal Bilimler Enstitüsü, Ankara.

Çubukçu, Z. ve Dündar, İ. (2003). Okul Yöneticilerinin İletişim Becerilerine İlişkin Öğretmen Algı ve Beklentileri. Milli Eğitim Dergisi, 157;

Dağlı, A., Elçiçek, Z., ve Han, B. (2018). Örgütsel bağlılık ölçeği'nin Türkçeye uyarlanması: Geçerlik ve güvenirlik çalışması. Elektronik Sosyal Bilimler Dergisi, 17(68), 1765-1777.

Doğan, Y. (2007). İlköğretim çağındaki 10-14 yaş grubu öğrencilerinin gelişim özellikleri. Uludağ Üniversitesi Fen-Edebiyat Fakültesi Sosyal Bilimler Dergisi, 8(13), 155-187.

Ergin, A. ve Cem B. (2000). Eğitimde iletişim. Ankara: Anı Yayıncılık.

Gülmez, S.B. (2017). Okul müdürlerinin iletişim yetkinliği becerileri. Yayınlanmamış Yüksek Lisans Tezi. Yeditepe Üniversitesi, Eğitim Bilimler Enstitüsü, İstanbul.

Gürgen, H. (1997). Örgütlerde iletişim kalitesi. İstanbul: Der Yayınları. 
Hoy, W.K. \& Miskel, C.G. (2012). Eğitim yönetimi, teori, araştırma ve uygulama. (Çev Ed. S. Turan). İstanbul: Nobel Yayın.

Karasar, N. (2008). Bilimsel araştırma yöntemi, İstanbul: Nobel Yayın.

Kıraç, E. (2012). Örgütsel iletişimin örgütsel bağlıık algılaması üzerindeki etkileri ve bir araştırma. Yayınlanmamış Yüksek Lisans Tezi. Pamukkale Üniv. Sosyal Bilimler Enstitüsü. Denizli

Konan, N., \& Mermer, S. (2021). Kuantum liderlik ölçeği: geçerlik ve güvenirlik çalışması. E-Uluslararası Pedandragoji Dergisi, 1(1), 74-86. Erişim: https://www.eijpa.com/index.php/pedandragoji/article/view/konan-mermer

Lunenburg, F.C. \& Ornstein, A.C. (2012). Eğitim yönetimi. (Çev.Ed. G.Arastaman). İstanbul: Nobel Yayın.

Luthans, F. (1995). Organizational behavior, New York: McGraw-Hill.

Mangır, M. Ve Çağatay-Aral, N. (1992). Ergenlik Dönemi Özellikleri ve Sorular, Gazi Eğitim Fakültesi Dergisi., Cilt:8 Sayı;4.

Meyer, J. S. \& Allen, N. J. (1991). A three- component conceptualization of organizational commitment. Human Resource Management Review, 1(1), 61-89.

Meyer, J. P., Allen, N. J. \& Smith, C. A. (1993). Commitment to organizations and occupations: Extensionand test of a three-component conceptualization. Journal of Applied Psychology. 78, 538-551.

Newstrom, J.W. \& Davis, K. (1993). Organizational behavior: human behavior at work. New York: McGrawHill

Ordu, A., Bakay, M. E., ve Tanrı̈ğgen, A. (2010). İlköğretim okulu öğretmenlerinin örgütsel bağlılık düzeyleri. Pamukkale Üniversitesi Eğitim Fakültesi Dergisi, 28, ss. 101-115

Robbins, S.P. \& Coulter, M. (2003). Management, New Jersey: Prentice Hall.

Saltık, B., Ünsar, A.S. ve Oğuzhan, A. (2015). Örgütsel iletişimin örgütsel bağlılığa olan etkisi. Finans Politik ve Ekonomik Yorumlar. 52 (600), 47-58

Serin, M. K. ve Buluç, B. (2012). İlköğretim okul müdürlerinin öğretim liderliği davranışları ile öğretmenlerin örgütsel bağlılıkları arasındaki ilişki. Kuram ve Uygulamada Eğitim Yönetimi, 3(3), 435-459.

Şimşek, Y. (2003). Okul müdürlerinin iletişim becerileri ile örgüt kültürü arasındaki ilişki. Yayımlanmamış doktora tezi. Eskişehir: Anadolu Üniversitesi Eğitim Bilimleri Enstitüsü.

Şişman, M. (2012). Öğretim liderliği. Ankara: Pegem Akademi.

Topluer, A. (2008). İlköğretim okulu yöneticilerinin iletişim yeterlikleri ile örgütsel çatışma düzeyi arasındaki ilişki (Malatya ili örneği). Inönü Üniversitesi, Malatya.

Toprakçı, E. (2001). Okul müdürlerinin iletişim yeterliği. Yaşadıkça Eğitim 71; Eylül-Temmuz, ss,29-33 Erişim: https://www.erdaltoprakci.com.tr/wp-content/uploads/2019/09/OKUL-MÜDÜRLERININ-ILETișiMYETERLILiĞi.pdf

Yıldız, P. (2019). Örgütsel bağlılı üzerinde örgütsel güven ve örgütsel iletişimin etkisini belirlemeye yönelik bir araştırma.. Yayınlanmamış Yüksek Lisans Tezi. Marmara Ün. Eğitim Bilimleri Enstitüsü. İstanbul

Yücel, I. ve Bektaş, C. (2012). Job satisfaction, organizational commitment and demographic characteristics among teachers in turkey: younger is better?. Procedia-Social and Behavioral Sciences, 46, 1598-1608. 


\section{The Effect of School Principals 'Communication Competencies on Teachers' Organizational Commitment}

\author{
Prof. Dr. Çağlar Çağlar \\ Adlyaman University -Turkey \\ ccaglar@adiyaman.edu.tr
}

\author{
Hasan Çınar \\ Adıyaman Provincial Directorate of \\ National Education-Turkey \\ ht.hasantosun@hotmail.com
}

\begin{abstract}
With this study, the effect of school principals' communication competencies on teachers' organizational commitment was aimed to be revealed. In the study, in order to determine the communication competencies of school principals, "Communication Skills Scale", adapted to Turkish by Topluer (2008), and "Organizational Commitment Scale, adapted to Turkish by Dağlı, Elçiçek, and Han (2018), were used. 341 teachers working in Adıyaman province participated in the study. The findings obtained revealed that perceived communication competencies differed among the groups according to the variables of school type, working period in the same institution, and professional seniority and that $38 \%$ of the organizational commitment behaviors (variance) of teachers was explained by the communication competencies of the school principals.
\end{abstract}

Keywords: Communication, Communication competencies, Organizational commitment, School principal

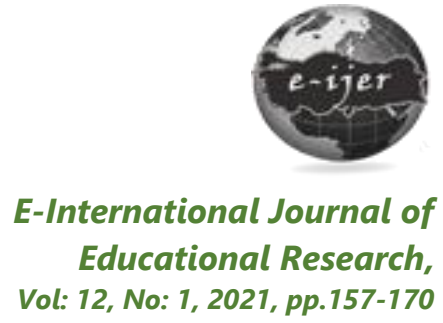

DOI: 10.19160/ijer.831956

\section{Suggested Citation:}

Çağlar, Ç. ve Çınar, H. (2021) The Effect of School Principals 'Communication Competencies on Teachers' Organizational Commitment , E-International Journal of Educational Research, Vol: 12, No: 1, 2021, pp. 157-170, DOI: 10.19160/ijer.831956 


\section{EXTENDED ABSTRACT}

Problem: Many factors affect the success and failure of communication, which can be explained as the sharing of emotions and thoughts between the sender and the receiver. The high level of communication skills of the people in managerial positions in organizations directly affects the climate of that organization and the happiness and work efficiency of the employees. One of the most important processes that play a role in the success of managers and the efficiency of organizations is the communication process. Communication, defined as the process of transmitting all kinds of concepts and symbols with the aim of changing human behavior, is an indispensable requirement for organization and management activities. Communication, which has a great impact on interpersonal relationships, is also an important process that ensures the regular functioning of school life. School principals spend most of their time communicating. In this context, as communication forms the basis of interpersonal, institutional, or administrative processes and the structure of schools, school administrators have to understand communication very well. Therefore, communication skills are a necessary tool for an effective manager. School principals have responsibilities such as establishing communication, coordination, and relationships between the inner and outer environment of the school. It is emphasized that the school administration should do activities such as establishing a communication network, influencing people, and managing conflicts in order to create a healthy and open school climate. It has been stated that one of the issues that a process-oriented school administrator will attach importance to in his (her school is healthy communication, and that open communication channels will help identify and solve many problems at school. On the other hand, closed communication channels, unhealthy functioning of communication, and lack of communication have a fatal impact on the school, just as the disruption of communication between the limbs of the body would kill the living creature. It has been stated that communication is the lifeblood of the school, an important management skill, and school administrators spend more than $70 \%$ of their time on communication (Açıkalın, Şişman ve Turan, 2011). In this study, it was aimed to determine the effects of school principals' communication competencies on teachers' organizational commitment.

The problem of the research can be summarized as follows: "What is the level of communication competence of school principals and organizational commitment of teachers? Are these levels affected by various variables (gender, type of school in the same school, professional seniority)? And finally, what effect does school principals 'perception of communication competencies have on teachers' organizational commitment?"

Based on previous research conducted, it was assumed that there was a relationship between the school principals' communication competencies and the organizational commitment of teachers. To increase teachers' organizational commitment, it is necessary that school principals establish positive communication. In this study, it was aimed to reveal to what extent the communication competencies of school principals affect teachers' organizational commitment.

Method: In the research, the relational screening model, one of the general survey types, was used. The universe of the study consisted of 9,561 teachers working in Pre-Schools, Primary Schools, Secondary Schools, and High Schools affiliated with MoNE in Adıyaman provincial center in the 2019-2020 academic year. The sample of the study was composed of 341 teachers.

In the study, "Communication Skills Scale", adapted to Turkish by Topluer (2008), and "Organizational Commitment Scale", developed by Meyer, Allen, and Smith (1993) and adapted to Turkish by Dağlı, Elçiçek, and Han (2018), were employed. In addition, the personal information form, which would serve as a basis for the analysis and interpretation of the data obtained from these scales, was also used along with the scales. 
Findings: In the t-test analysis conducted in order to determine whether the perceived communication competencies of school principals and the organizational commitment levels of teachers differed according to the gender variable, no statistically significant difference was found between the groups in terms of gender.

In the analysis performed in order to identify whether the perceived communication competencies of school principals and the organizational commitment levels of teachers varied according to the institution they worked in, a statistically significant difference was found between the groups. Communication competence perceptions of the teachers working in pre-school education institutions, the teachers working in primary schools, and the teachers working in high schools were determined to be more positive than the communication competence perception of the teachers working in secondary schools.

In the analysis performed in order to determine whether the perceived communication competencies of school principals and the organizational commitment levels of teachers differed according to the variable of working period in their current institution, no statistically significant difference was identified between the groups. It was observed that as the working period of teachers in their institution increased, their perception of communication competencies improved.

In the analysis done in order to determine whether the perceived communication competencies of school principals and the organizational commitment levels of teachers varied according to the professional seniority variable, while no significant difference was found between the groups, a significant difference between the variables of teachers 'organizational commitment level and teachers' professional seniority was found. It was observed that the organizational commitment levels of teachers with professional seniority of 21 years and more were higher than the others with less seniority.

In the regression analysis carried out in order to determine the effect of perceived communication competencies of school principals on the organizational commitment levels of teachers, it was observed that the communication competencies of school principals affected teachers' organizational commitment behaviors positively at a moderate level. The data obtained showed that $38 \%$ of the organizational commitment behavior (variance) of teachers was explained by the communication competencies of school principals.

To increase the communication competencies of school principals in terms of increasing the organizational commitment levels of teachers, in-service training courses to be provided by the Ministry of National Education will be an appropriate practice. Newly appointed school principals who start to work should have the knowledge and skills to ensure communication within the organization along with other areas deemed necessary.

Practices should be implemented to encourage teachers to work longer in the educational institution where they work. The Ministry of National Education is currently following a policy of a $50 \%$ increase in the annual service points earned in order to ensure that teachers work longer in certain regions and schools. Similar practices can be applied to extend the working period of teachers in the same school. 